\title{
Psoroma nivale (Pannariaceae, lichenized ascomycota) a new species from arctic Québec, Canada with dark, elongate squamules and bacilliform ascospores
}

\section{Alan M. FRYDAY, Arve ELVEBAKK, Frances L. ANDERSON and Jean Y. GAGNON}

A.M. Fryday: Herbarium, Dept Plant Biology, Michigan State University, East Lansing, MI 48824, USA.Email: fryday@msu.edu

A. Elvebakk: Tromsø University Museum, University of Tromsø - the Arctic University of Norway, P.O. Box 5060 Langnes, NO-9037 Tromsø, Norway.

F.L. Anderson: 273 Crouse's Settlement Rd., Upper LaHave, NS, B4V 0G4, Canada.

J.Y. Gagnon: Ministère des Forêts, de la Faune et des Parcs, Direction des parcs nationaux, 880, chemin Ste-Foy, RC-2.5, Québec, QC, G1S 4X4, Canada.

\begin{abstract}
The new species Psoroma nivale is described from an area of late snow-lie in the Keglo Bay area on the eastern side of Ungava Bay northern Québec, Canada. It is superficially similar to $P$. hypnorum but has a dark, brownish black thallus colour without reddish hues, much-branched, proliferating squamules, thick paraphyses, distinct, but inconspicuous IKI + ascus tube structures, and characteristic elongate, bacilliform, often asymmetrical ascospores. The new species is compared with possibly related taxa and its systematic position discussed. A key to the species of pannarioid lichens reported from arctic areas of North America is also provided.
\end{abstract}

Key words: identification key, late snow-lie, Nunavik, perispore, taxonomy, variable ascus structure

\section{Introduction}

Traditionally, the genus Psoroma Ach. ex Michx. was the main genus of the Pannariaceae, in which the species typically had a green chlorococcoid alga as the primary photobiont. However, Jørgensen (2001) showed that some of the large foliose austral species with a chlorococcoid photobiont previously included in Psoroma were better placed in Pannaria Delise ex Bory. He formally transferred three of them to Pannaria and this process has been continued by other researchers (Elvebakk \& Galloway 2003; Passo \& Calvelo 2006). More recently, several segregate genera have been split off from Psoroma; the Paleotropics species 
to Gibbosporina Elvebakk, S.G. Hong \& P.M. Jørg. (Elvebakk et al. 2016) and other Southern Hemisphere groups to Joergensenia Passo, S. Stenroos \& Calvelo, (Passo et al. 2008) as well as Psorophorus Elvebakk \& S.G. Hong and Xanthopsoroma Elvebakk \& S.G. Hong (Elvebakk et al. 2010).

In this revised circumscription, the genus Psoroma is mostly confined to mid to high latitude regions, but also with representatives at high altitudes in tropical countries like Ecuador (Jørgensen \& Palice 2010). The genus is most species-rich in the Southern Hemisphere; for example, the most recent lichen checklist for Chile (Galloway \& Quilhot 1998) lists 35 taxa, but 13 of these have been removed to other genera and seven are synonyms (see above and Jørgensen 2003), leaving a total of 15. In contrast, only five species have been reported from the Northern Hemisphere (Henssen \& Renner 1981; Jørgensen 2000 [2001], 2004; Timdal \& Tønsberg 2006; Elvebakk 2012; Elvebakk \& Tønsberg 2018) and two of these species are known from only single collections (P. cinnamomeum Malme from southern California and P. spinuliferum Elvebakk \& Tønsberg from coastal Alaska). Molecular investigation of the Pannariaceae by Ekman et al. (2014) showed that another taxon, Psoroma tenue Henssen, was not congeneric with the type species of the genus, $P$. hypnorum (Vahl) Grey, although they were unable to suggest the correct placement for this species because of the lack of resolution in that part of their phylogeny.

Here we describe a further species for the Northern Hemisphere that is known only from an area of late snow-lie in northern Québec, Canada (Fig. 1). We also discuss its systematic position within the Pannariaceae and provide a key to pannarioid lichens in arctic areas of North America.

\section{Materials and Methods}

Apothecial characteristics were examined by light microscopy on hand-cut sections mounted in water, $10 \% \mathrm{KOH}(\mathrm{K}), 50 \% \mathrm{HNO}_{3}(\mathrm{~N})$ or Lugol's reagent $(0.15 \%$ aqueous IKI). Thallus sections were investigated in water and $\mathrm{K}$. The ascus structure was studied in IKI, both without prior treatment and after pretreatment with K. Measurements of ascospores and paraphyses were made in water. Only ascospores liberated from asci were studied. Nomenclature of ascospore structures follows Nordin (1997) and proper ascospores and perispores were measured separately. Sketches of a total of 20 ascospores and the IKI + structures of c. 70 asci were drawn and a selection made to represent the variation observed. Thin layer chromatography followed the methods of Orange et al. (2001). 
Selected additional collections examined: Austrella arachnoidea P. M. Jørg. French Southern and Antarctic Lands: Îles Kerguelen: Île Guillou, 49²8'57"S, 6949'06"E, 14m, feldfield, 2014, D. Ertz 18847 (MSC0242550).

Austrella isidioidea P. M. Jørg. \& Fryday Falkland Islands: West Falkland: Port Howard, Mt. Maria, Lightning Rocks, 51.619028 ${ }^{\circ}$ S, 59.601849º W, 575 m., over Andreaea sp. in recess on exposed, E-facing rocks, 2015, Fryday 10918 (MSC0195379).

Fuscopannaria pacifica P.M. Jørg. USA: Alaska: Hoonah-Angoon District, Glacier Bay National Park, Bartlett Lake Road, $58.46350^{\circ},-135.77520^{\circ}$, mixed woodland, alder twigs, 2012, Fryday 9900 (MSC0256265).

Pannaria euphylla (Nyl.) Elvebakk \& D.J. Galloway New Zealand: South Island: at junction of Craigieburn River and Route 73, mature Nothofagus forest in ravine, 1971, H. A. Imshaug 48263 (MSC0140775).

Pannaria xanthomelana (Nyl.) Hue New Zealand: The Auckland Islands: Adams Island, slope of Magnetic Station, southwest of Camp Cove, Carnley Harbour, Metrosideros forest, 1973, H. A. Imshaug 57459 (MSC0242519).

Protopannaria hilaris (Zahlbr.) P.M. Jørg. Chile: Juan Fernandez Islands: Mas a Tierra, Portezuelo de Villagra, Villagra side of saddle, Drimys forest, 550 m, 1965, H. A. Imshaug 37627B (MSC0011743); ibid., 1-200 m E of the mountain pass between Quebrada Vaquería and Valle Ingles, $33^{\circ} 37^{\prime} \mathrm{S}, 78^{\circ} 51^{\prime} \mathrm{W}, 400$ m, on Escallonia, 2006, Elvebakk 06:368 (TROM).

Protopannaria pezizoides (Weber) P.M. Jørg. \& S. Ekman USA: Wyoming: Big Horn Co., Bighorn National Forest, USFS 28 at North Fork of Crazy Woman Creek, $20.5 \mathrm{mi}$ (33 km) SW of

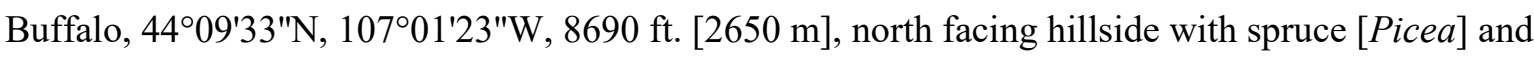
few fir [Abies], 2007, C.M. Wetmore 96618 (Lichenes Exsiccati \#215) (MSC0108446). Norway: Troms: Karlsøy, Vanna, Djupvik, on limestone debris, 10 m, 25 June 1994, Engelskjøn \& Aasen (TROM).

Psoroma angustisectum Zahlbr. Chile: Juan Fernandez Islands: Mas Afuera, Los Inocentes, south summit, heath with Lophosoria, 1300 m, 1965, H. A. Imshang 37416 A (MSC0162040).

Psoroma buchananii (C. Knight) Nyl. Chile: Magallanes: Morro Chico, over bryophytes on a vertical S-facing cliff wall, 52 03'S, 71 24'W, 200 m, 1999, Elvebakk 99:1236 (TROM).

Psoroma hypnorum (Vahl) Gray. USA: Wyoming: Teton Co., Yellowstone National Park, Elephant Back Ridge, 1.5 miles (2.4 km) west of Fishing Bridge; 443' $17 " \mathrm{~N}, 110^{\circ} 24^{\prime} 27^{\prime \prime} \mathrm{W}, 8600 \mathrm{ft}$, on ridge with lodgepole pine (Pinus contorta) and some whitebark pine (Pinus albicaulis), 1998, C. M. Wetmore 81768 (MSC0108449). Alaska: Hoonah-Angoon District, Glacier Bay National Park, Willoughby Island, $58.60809^{\circ},-136.117358^{\circ}$, terricolous, calcareous shoreline heath, 2011, Fryday 9715 (MSC0154284). 
Psoroma polychidioides (Zahlbr.) P.M. Jørg. Falkland Islands: West Falkland: Hill Cove, NE base of French Peaks, UTM 21F TC 8188, 200 ft., stone run, 1968, H. A. Imshang $41019 \& R$. C. Harris. (MSC0136449).

Psoroma tenue var. tenue Henssen Argentina: Tierra del Fuego: Ushuaia, Río Olivia, on rocks by the river, 1940, Santesson 971 (S).

Psoroma tenue var. boreale Henssen Norway: Troms: Tromsøya, Telegrafbukta, on mosses between N-facing rocks, 2 m, just above the littoral zone, 2009, Elvebakk 09:039 \& S. G. Hong (TROM).

'Santessoniella' arctophila (Th. Fr.) Henssen USA: Alaska: Hoonah-Angoon District, Glacier Bay National Park, Muir Point, $58.83415^{\circ} \mathrm{N}, 136.05753^{\circ} \mathrm{W}, 4 . \mathrm{m}$., terricolous/muscicolous, in flat area behind sea-bank, Plantago zone, 2012, Fryday 10221, T. Spribille \& M. Svensson (MSC);

Norway: Troms: Kåfjord/Gáivuona, $300 \mathrm{~m} \mathrm{~N}$ of the inlet Stuoraluokta of lake Guolasjávri, on calcareous mineral soil on an exposed Dryas ridge, $69^{\circ} 22^{\prime} \mathrm{N}, 21^{\circ} 06^{\prime} \mathrm{E}, 840 \mathrm{~m}, 2011$, Elvebakk 11:021 (TROM).

Xanthopsoroma contextum (Stirt.) Elvebakk \& S.G. Hong New Zealand: The Auckland Islands: Auckland Island, tussock above Ranui Cove, mosaic of low scrub and tussock, 1972, H. A. Imshaug 56192 (MSC0136326).

\section{The Species}

\section{Psoroma nivale Fryday, Elvebakk, F.L. Anderson \& J. Gagnon sp. nov.} MycoBank No.: MB 831357

Superficially similar to $P$. hypnorum, but differing in having a dark brown to black thallus without reddish hues, more finely-dissected squamules, less prominant internal IKI+ tube structures within the asci, presence of strongly swollen paraphyses, and narrow, elongate and \pm bacilliform ascospores (1/b ratio:2.5-3.0), without large, apical perispore extensions.

Type: Canada, Québec, Nunavik, Keglo Bay, 34.1 km east-north-east of Kangiqsualujjuaq, $15.2 \mathrm{~km}$ east-south-east of lake Qarliik, $12.8 \mathrm{~km}$ south of Baudan river, 8.8 $\mathrm{km}$ south-south-east of Lake Angusik, $0.9 \mathrm{~km}$ west of an unnamed stream, $58.84867^{\circ} \mathrm{N}$, $65.44511^{\circ} \mathrm{W}, 321 \mathrm{~m}$, over Andreaea rupestris on low boulder below area of prolonged snow lie, 1 August 2016, J. Y. Gagnon 31.1 (QFA: SF16-1315-holotype).

(Figs 2-4)

Thallus composed of small, horizontal to ascending, elongated, dissected and proliferating squamules, much branched with terminal lobes up to $1 \mathrm{~mm}$ long; end lobes $c$. $0.2 \mathrm{~mm}$ wide, mostly \pm flat but becoming rounded, $0.1-0.2 \mathrm{~mm}$ thick; brownish black when 
dry becoming sordid yellow in shaded areas; lower surface sordid yellow. Cortex blackish brown pigmented, mostly composed of five or more layers of prosoplectenchyma, cells c. 10$15 \times 3 \mu \mathrm{m}$, but cortex of upper surface $c .20 \mu \mathrm{m}$ thick and composed of \pm isodiametric cells (paraplectenchyma) to $10 \mu \mathrm{m}$ across. Cephalodia present in basal parts of thalli, common, but black and inconspicuous, pulvinate to irregularly coralloid, $0.2-1 \mathrm{~mm}$ diam. Primary photobiont Trebouxia, cells 9-15 $\mu \mathrm{m}$ with thick hyaline wall c. $2 \mu \mathrm{m}$ wide, and finely papillose chloroplasts. Secondary photobiont Nostoc, individual cells blue-green, 5-8 $\times 3-7$ $\mu \mathrm{m}$, ellipsoid to irregularly angular, arranged in glomeruli without visible chain structures.

Apothecia common, lecanorine, sessile with a narrow base, arising from the upper surface of the squamules; initially flat, $0.4-0.8 \mathrm{~mm}$ diam, but up to $3 \mathrm{~mm}$ across with an irregular, often lobed outline and undulating surface when mature, covering much of the surface of the central part of the thallus; disc red when young becoming black when mature and turning dark red-brown when wet; thalline margin thick, raised, $0.1-0.15 \mathrm{~mm}$ wide, entire with shallow radial fissures when young, composed of proliferating \pm digiform to coralloid, slightly flattened squamules similar to those of the thallus when mature. Exciple 150-175 $\mu \mathrm{m}$ wide, cupular and finely white-tomentose below, algae present, the same as in thallus, hyaline, composed of radiating hyphae 4-5 $\mu \mathrm{m}$ wide, cells 5-18 $\mu \mathrm{m}$ long, cortical cells dark brown pigmented $(\mathrm{N}+\mathrm{red})$. Hymenium c. $150 \mu \mathrm{m}$ tall, IKI+ strongly blue, paraphyses 3-4 $\mu \mathrm{m}$ wide, in mid hymenium, gradually widening to 5-7 $\mu \mathrm{m}$ wide at the apex with a brown pigmented cap that sometimes forms a sheath around the terminal cell, simple, rarely branching above, septate, constricted at the septa, sometimes almost moniliform; epihymenium dilute brown. Hypothecium c. $50 \mu \mathrm{m}$ deep, hyaline to dilute orange-brown. Asci cylindrical c. 100-120 × 15-20 $\mu \mathrm{m}$, apical structure variable, usually with an IKI+ blue external cap and one or more IKI+ blue \pm horizonal sheets in the upper tholus, but some asci have only the external cap, whereas others have a weak, but distinct IKI+ blue tube structure; proper ascospores hyaline, narrow elongate with rounded ends, mostly bacilliform, or weakly asymmetrical, $17-21 \times 5.5-8 \mu \mathrm{m}(1 / \mathrm{b}$ ratio: c. $2.5-3.0)$, perispores of the same shape, regularly low-verrucose, without or with modest pulvinate apical extensions, $18-22 \times 6-8.5$ $\mu \mathrm{m}$, perispore gradually degenerating in $\mathrm{K}$, but swelling to $4-5 \mu \mathrm{m}$ thick in $\mathrm{N}$.

Conidiomata not observed.

Chemistry. All spot tests negative; no substances detected by TLC. 
Distribution and Ecology. Psoroma nivale is known only from the type collection where it grew over Andreaea rupestris Hedw. on the upper surface of a low acidic boulder associated with glacial till at the lower edge of an area of late snow-lie (slope: 15\%; aspect: $70^{\circ}$ ). Also present on the same boulder were Cladonia sp., Micarea incrassata Hedl., Peltigera sp. and Rhizocarpon sp. Other cryptogams recorded from the vicinity are given in Table 1 . The surrounding vegetation consisted of a dwarf shrub community dominated by Salix herbacea L. with Carex bigelowii Torr. ex Schwein. The Keglo Bay site is situated within the Arctic shrub tundra domain (Ministère des Forêts, de la Faune et des Parcs, 2019; Elvebakk et. al., 1999).

Remarks. The perispore of the ascospores of the new species expands dramatically in $\mathrm{N}$, from $c .1 \mu \mathrm{m}$ to $4-5 \mu \mathrm{m}$. We could find no mention of this phenomenon in the literature and so were unsure whether it was restricted to our new species or was common to other species of the genus, or even family. Consequently, we tested specimens of several other species of Psoroma and other Pannariaceae genera from the MSC herbarium (see "Additional Collections Examined" above) and discovered that the perispore expanded in $\mathrm{N}$ in the studied species of Psoroma and Pannaria, all with a warted perispore, but not in the smooth-spored Fuscopannaria pacifica.

Systematic position. Initially, we thought that our collection might represent an extreme environmental modification of Psoroma hypnorum, but we soon dismissed this idea because of the characteristic elongate, ascospores, always without large apical extensions (Fig. 3G, 4), as well as the very thick paraphyses (4-7 $\mu \mathrm{m}$; Fig. 3E), both of which are very different from those of $P$. hypnorum. The amyloid reaction of the ascus apex was also confusing. The asci of P. hypnorum have a well-defined IKI+ blue tube structure (Fig. 4C in Elvebakk et al. 2010), whereas the ascus structure of our new species appears variable. Most asci had an IKI+ blue external cap and one or more IKI+ blue \pm horizonal sheets in the upper tholus (Fig. 4), whereas weak, but distinct tube structures were also rarely observed (Fig. 3F, 4). This is possibly due to differing degrees of maturity of the asci, with immature asci having only the external cap that later develop the internal horizontal sheets, with the tube-like structure developing only in fully mature asci. A similar process has been documented in the asci of Xenolecia Hertel, with immature asci having an internal cap (Lecidea-type) that develop a tube structure (Porpidia-type) on maturity (Fryday \& Thüs 2007). 
At first, the ascus characters of our new species appeared to exclude from consideration not only P. hypnorum but also the genus Psoroma in general. Because the shape and colour of the thallus squamules of our new species resemble those of a species of Fuscopannaria P.M. Jørg. and, also as in some Fuscopannaria species, it has apothecia with squamulose margins that are sunken below the squamules, our next thought was that it might be a species of Fuscopannaria with a chlorococcoid photobiont. Although the photobiont in Fuscopannaria is usually a cyanobacterium, one species, Fuscopannaria viridescens P.M. Jørg. \& Zhurb., does have a green chlorococcoid photobiont and occurs in the North American Arctic. However, that species has a fawn brown thallus with expanded marginal lobes (Jørgensen \& Zhurbenko 2002, Nelson \& Wheeler 2013) and because the ascospores of Fuscopannaria species have a smooth surface (James \& Jørgensen 2009) and their hymenia are IKI + reddish brown, we excluded that genus from consideration for our species.

Based on the amyloid reaction of the ascus structure and the ascospores with a warted perispore, we next considered whether our collection could be accommodated in Protopannaria P.M. Jørg. However, all described species of Protopannaria have a cyanobacterium as photobiont and comparison with P. pezizoides (Weber) P.M. Jørg. \& S. Ekman, the type species of the genus, revealed that our species had very little else in common with that genus. Protopannaria pezizoides differed in having a completely different thallus structure and apothecial anatomy with an adglutinated epihymenium of thin paraphyses, and asci with very distinct, external IKI + blue apical caps. Some internal sheets were observed, but no tube structures. We also looked at several of the Southern Hemisphere species referred to Protopannaria, which differed widely from both $P$. pezizoides and each other. For example, Protopannaria hilaris (Zahlbr.) P.M. Jørg., described from the Juan Fernández Islands (Chile) had ascus IKI+ reactions different from those of $P$. pezizoides. The external caps were not so dominant, internal sheet-like structures were well developed, but many cases of true tube structures were also observed. However, unlike our new species, its ascospores were small and short-ellipsoid. Protopannaria, as presently understood, includes seven species but it appears to be heterogeneous and definitively in need of further study.

This brought us back to our original opinion, that the new species could only be accommodated in a widely circumscribed Psoroma as depicted by Ekman et al. (2014; clade 2c). However, as the paraphyses are different and the IKI + tube structures less pronounced compared to those of $P$. hypnorum (the type species) we checked the phylogeny of Ekman et al. (2014) for other taxa in their 'clade 2c' that might be congeneric with our species. Among these, Psorophorus ssp. and Psoroma tenue have well-developed IKI+ apical tube structures, 
but no other similarities to our new species, except that $P$. tenue var. tenue has similar paraphyses. Austroparmeliella lacerata (P.M. Jørg.) P.M. Jørg. is also very different, including having smooth ascospores, and the two Austrella species do not have IKI+ blue hymenia, and were recently found to be paraphyletic (Fryday et al. 2017). This left us with 'Santessoniella' arctophila, which is not a very useful reference for defining generic positions, as the type species of the genus, $S$. polychidioides (Zahlbr.) Henssen, was recovered within the core Psoroma clade by Ekman et al. (2014), leaving S. arctophila as an orphaned taxon. Our studied material of ' $S$.' arctophila may be heterogeneous; Elvebakk 11:021 has asci with a combination of IKI+ sheets and true tubes, but the smooth ascospores are devoid of visible perispore structures, whereas Fryday 10221 and the type collection in UPS have ascospores with a warted perispore.

Within Psoroma, our new species is distinguished primarily by its unique ascospore shape (Fig. 3G), a character that is unknown in any previously described species of the genus: ascospores of Psoroma species are predominantly ellipsoid, whereas some are ovoid and others weakly or strongly citriform. We have searched for Psoroma species with a similar morphology with regard to other characters, particularly in the Southern Hemisphere, where the genus definitively has its evolutionary origin. Psoroma angustisectum Zahlbr., a rare species described from the Juan Fernandez Islands and also reported from southern mainland Chile and New Zealand, has long and dissected squamules, but they have the brown melanin colour of $P$. hypnorum and its ascospores have been described as much larger, 25-35(-38) $\times$ 10-15 $\mu \mathrm{m}$ (Galloway 2007).

Most Psoroma species share the reddish-brown hues of $P$. hypnorum, or may even be cinnamon-coloured, like $P$. tenue var. boreale. However, the species matching the colour of $P$. nivale most closely, may be the panaustral species $P$. buchananii. It has a dark, blackish brown melanin colour, which can take on a more mustard-yellow colour, as in the holotype of $P$. nivale, probably in shaded parts of the thallus. However, the squamules of $P$. buchananii are much less branched, it has conspicuous black pycnidia, and the ascospores are shortellipsoid to subglobose with rather scattered, wide gibbae, instead of regularly set verrucae.

We conclude that there are no known species from the Southern Hemisphere resembling $P$. nivale in a combination of melanin colours and anatomical and macroscopic characters. The new species will be included among extensive phylogenetic studies that are needed, both to challenge the present paraphyletic position of Psoroma shown both by Ekman et al. (2014) and Park et al. (2018), and to define its nearest neighbouring genera. It is also our hope that 
the present paper can stimulate further searches in the field for this species, so far only known from its holotype specimen.

\section{Key to species of Pannariaceae and similar families (Koerberiaceae. Massalongiaceae, Vahliellaceae) reported from arctic regions of North America.}

Geographically, the Arctic is that area of the Earth north of the Arctic Circle but, biologically, this is of little relevance because it makes no allowance for altitude or continental position the other main drivers of climatic conditions and the resulting vegetation. Elvebakk (1999) proposed a bioclimatic delimitation of the 'Arctic' based on the presence of arctic vegetation that corresponds to that area north of the tree-line. This has been refined by the CAVM Team (Walker et al. 2005) who have produced detailed maps of Arctic vegetation. The dominant vegetation of the Keglo Bay area is low shrub tundra, which is characteristic of the 'Low Arctic'.

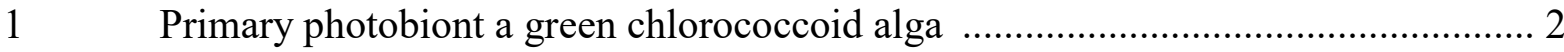

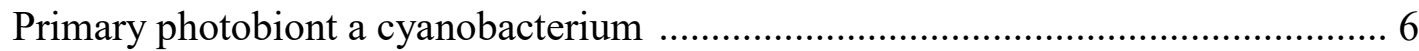

2(1) Thallus placodioid, fawn brown with wide radiating marginal lobes

Fuscopannaria viridescens

Thallus composed of small squamules without a well-defined margin 3

3(2) Apothecia lacking a thalline margin

Vahliella globigera (Fryday \& P.M. Jørg.) P.M. Jørg.

Apothecia with a well-developed thalline margin

4(3) Squamules elongate, much-branched, dark brownish-black, ascospores bacilliform

Psoroma nivale

Squamules rounded to granular, not branched, green to chestnut-brown, ascospores wide ellipsoid to citriform

5(4) Thallus of greenish-brown to brown squamules; apothecial margin squamulose. Thallus lacking lichen substances 
Thallus of reddish-brown, small and glossy granules; apothecial margin granular, Thallus containing porphyrilic acid methyl ester and pannaric acid

Psoroma tenue var. boreale

6(1) Thallus with soredia, sorediose isidia, isidia or coralloid granules 7

Thallus lacking soredia, sorediose isidia and isidia, usually fertile 11

7(6) Thallus with true isidia or coralloid granules .8

Thallus with soralia or sorediose isidia (gymnidia) 10

8(7) Squamules on a blue-black hypothallus, on rocks or trees; ascospores simple

Parmeliella triptophylla (Ach.) Müll. Arg.

Hypothallus absent 9

9(8) Thallus of flat squamules, not adpressed to the surface; usually among bryophytes on rocks or on the ground; ascospores 1-septate

Massalongia carnosa (Dicks.) Körb.

Thallus of narrow radiating lobes, directly on rock; ascospores simple

Tingiopsidium isidiatum (Degel.) Hafellner \& T. Sprib.

10(7) Thallus with enlarged, radiating marginal lobes

Fuscopannaria ahlneri (P.M. Jørg.) P.M. Jørg. Thallus lacking enlarged, radiating marginal lobes Pannaria conoplea (Ach.) Bory

11(6) Thallus composed of brown, ascending, frosted lobes, apothecia rare

Fuscopannaria praetermissa (Nyl.) P.M. Jørg.

Thallus otherwise; apothecia usually present 12

12(11) Thallus subfruticose, composed of ascending greenish black lobes; apothecia greenish-black Leciophysma finmarkicum $\mathrm{Th}$. Fr.

Thallus crustose, squamulose or of radiating lobes 13

13(12) Thallus \pm crustose, in small patches, apothecia lacking a thalline margin 14 Thallus squamulose or of radiating lobes, apothecia with a thalline margin 15 
14(13) Thallus olivaceous, apothecia dark brown, ascospores smooth

Leciophysma furfurascens (Nyl.) Gyeln.

Thallus brown; apothecia red-brown, ascospores with a warted perispore

"Santessoniella" arctophila*

15(13) Apothecia red-brown

Protopannaria pezizoides

Apothecia black

16

16(15) Thallus of narrow, fawn-brown radiating lobes

Tingiopsidium elaeinum (Wahlenb.) Hafellner \& T. Sprib.

Thallus squamulose or subfruticose

17(16) Thallus grey-white, placodioid to squamulose on a black hypothallus

Pannaria hookeri (Borrer) Nyl.

Thallus forming small, greenish-brown cushions

Vahliella hookerioides (P.M. Jørg.) P.M. Jørg.

*The type species of Santessoniella has been shown to belong in Psoroma.

We thank the Kativik Regional Government for organising and conducting botanical inventories in the Keglo Bay area on the east shore of Ungava Bay, Nunavik Québec, Canada, and Måns Svensson (UPS) for checking the ascospores of the type collection of Pannaria arctophila. Two specimens used in this study (Fryday 9715 \& 9900) were collected from Glacier Bay NP as part of NPS project \#:R9815110518.

\section{REFERENCES}

Ekman, S., Wedin, M., Lindblom, L. \& Jørgensen, P. M. (2014) Extended phylogeny and a revised generic classification of the Pannariaceae (Peltigerales, Ascomycota). Lichenologist 46: 627-656.

Elvebakk, A. (1999) Bioclimatic delimitation and subdivision of the Arctic. In: The species concept in the High North - A Panarctic Flora Initiative (I. Nordal \& V. Y. Razzhivin (eds.): Det Norske Videnskaps-Akademi I. Matematisk-Naturvidenskapelig Klasse, Skrifta Ny Serie 38: 81-112. 
Elvebakk, A. (2012) An overlooked Psoroma in Denmark and southern parts of Sweden. Graphis Scripta 24: 45-48.

Elvebakk, A. \& Galloway, D. J. (2003) Notes on the heterogeneous genus Psoroma s. lat. in New Zealand. Australasian Lichenology 53: 4-9.

Elvebakk, A. \& Tønsberg, T. (2018) Psoroma spinuliferum (Pannariaceae), a new corticolous lichen species from Alaska with two different types of cephalodia. Bryologist 121: $166-173$.

Elvebakk, A., Elven, R. \& Razzhivin, V.Y. (1999) Delimitation, zonal and sectorial subdivision of the Arctic. In: The species concept in the High North - A Panarctic Flora Initiative (I. Nordal \& V. Y. Razzhivin (eds.): Det Norske Videnskaps-Akademi I. Matematisk-Naturvidenskapelig Klasse, Skrifta Ny Serie 38: 375-386.

Elvebakk, A., Robertson, E. H., Park, C. H. \& Hong, S.G. (2010) Psorophorus and Xanthopsoroma, two new genera for yellow-green, corticolous and squamulose lichen species, previously in Psoroma. Lichenologist 42: 563-585.

Elvebakk, A., Hong, S.G., Park, C. H., Robertson, E. H., \& Jørgensen, P. M. (2016) Gibbosporina, a new genus for foliose and tripartite, Palaeotropic Pannariaceae species previously assigned to Psoroma. Lichenologist 48: 13-52.

Fryday, A. M. \& Thüs, H. (2017) The genus Xenolecia (Lecideaceae s. lat., Lecanoromycetidae inc. sed.), including a second species in the genus from Campbell Island, New Zealand. Lichenologist 49: 365-372.

Fryday, A. M., Ertz, D. \& Jørgensen, P. M. (2017) Insights into the genus Austrella (Pannariaceae, Peltigerales), including a new species from the Falkland Islands. Lichenologist 49: 57-65.

Galloway, D. J. (2007) Flora of New Zealand Lichens. Revised Second Edition Including Lichen-Forming and Lichenicolous Fungi. Volumes 1 and 2. Lincoln, New Zealand: Manaaki Whenua Press.

Galloway, D. J. \& Quilhot, W. (1998) Checklist of Chilean lichen-forming and lichenicolous fungi [Lista patron de los liquenes y hongos liquenicolas de Chile]. Gayana Botanica 55: 111-185.

Henssen, A. \& Renner, B. (1981) Studies in the lichen genus Psoroma I. Psoroma tenue and Psoroma cinnamomeum. Mycotaxon 13: 433-449.

James, P. W. \& Jørgensen, P. M. (2009) Fuscopannaria P.M. Jørg. (1994). In: The Lichens of Great Britain and Ireland (C. W. Smith, A. Aptroot, B. J. Coppins, A. Fletcher, O. L. Gilbert, P. W. James \& P. A. Wolseley, eds): 411-413. London: British Lichen Society. 
Jørgensen, P. M. (2000) Survey of the lichen family Pannariaceae on the American continent, north of Mexico. Bryologist 103: 670-704.

Jørgensen, P. M. (2001) New species and records of the lichen family Pannariaceae from Australia. Bibliotheca Lichenologica 78: 109-139.

Jørgensen, P. M. (2003) Conspectus familiae Pannariaceae (Ascomycetes lichenosae).

Ilicifolia 4: 1-79.

Jørgensen, P. M. (2004) Psoroma tenue var. boreale, an overlooked, widespread, arcticalpine lichen. Graphis Scripta 15: 60-64.

Jørgensen, P.M. \& Palice, Z. (2010) Additions to the lichen family Pannariaceae in Ecuador. Nordic Journal of Botany 28: 623-628.

Jørgensen, P. M. \& Zhurbenko, M. (2002) Two new, remarkable, arctic species in the lichen genus Fuscopannaria (Pannariaceae, lichenized Ascomycetes). Bryologist 105(3): 465469.

Ministère des Forêts, de la Faune et des Parcs (2019) https://mffp.gouv.qc.ca/forets/inventaire/inventaire-zones-carte.jsp. Accessed 20 May 2019.

Nelson, P. R. \& Wheeler, T. (2013) Cephalodia found on Fuscopannaria viridescens. Lichenologist 45: 694-696.

Nordin, A. (1997) Ascospore structures in Physciaceae: an ultrastructural study. Symbolae Botanicae Upsalienses 32(1): 195-208.

Orange, A., James, P. W. \& White, F. J. (2001) Microchemical Methods for the Identification of Lichens. London: British Lichen Society.

Park, C. H., Hong, S. G, \& Elvebakk, A. (2018) Psoroma antarcticum, a new lichen species from the Antarctic and neighbouring areas. Polar Biology 41: 1083-1090.

Passo, A. \& Calvelo, S. (2006) New reports and combinations in the family Pannariaceae (Lecanorales, lichenized Ascomycota). Lichenologist 38: 549-555.

Passo, A., Stenroos, S. \& Calvelo, S. (2008) Joergensenia, a new genus to accommodate Psoroma cephalodinum (lichenized Ascomycota). Mycological Research 112: 1465 1474.

Timdal, E. \& Tønsberg, T. (2006) Psoroma paleaceum comb. nov. the only hairy Psoroma in northern Europe. Graphis Scripta 18: 54-57.

Walker, D. A., Raynolds, M. K., Daniëls, F. J. A., Einarsson, E., Elvebakk, A., Gould, W. A., Katenin, A. E., Kholod, S. S., Markon, C. J., Melnikov, E. S., et al. (2005) The Circumpolar Arctic Vegetation Map. Journal of Vegetation Science, 16:267-282. 



\section{Figure captions}

FIG. 1: Map showing the location of Keglo Bay, from where the new species was collected.

FIG. 2: Psoroma nivale (holotype). A, habitat. Psoroma nivale occurred on a low boulder just below the centre of the snow patch; $\mathrm{B}$. habit; $\mathrm{C}$, thallus with apothecia. $\mathrm{Scale}=2 \mathrm{~cm}$.

FIG. 3: Psoroma nivale (holotype). A, immature apothecium; B, mature apothecia; $\mathrm{C}$, lower cortex; D, section through mature apothecium; E, paraphyses; F, ascus in IKI; G.

ascospore in water; $\mathrm{H}$, ascospores in $70 \%$ nitric acid. Scales: $\mathrm{A}=0.5 \mathrm{~mm} ; \mathrm{B}=2.0 \mathrm{~mm} ; \mathrm{C}$, $\mathrm{F}-\mathrm{H}=10 \mu \mathrm{m} ; \mathrm{D}=100 \mu \mathrm{m} ; \mathrm{E}=5 \mu \mathrm{m}$.

FIG. 4. Ascospores, asci and paraphyses of Psoroma nivale. Scale $=10 \mu \mathrm{m}$. 


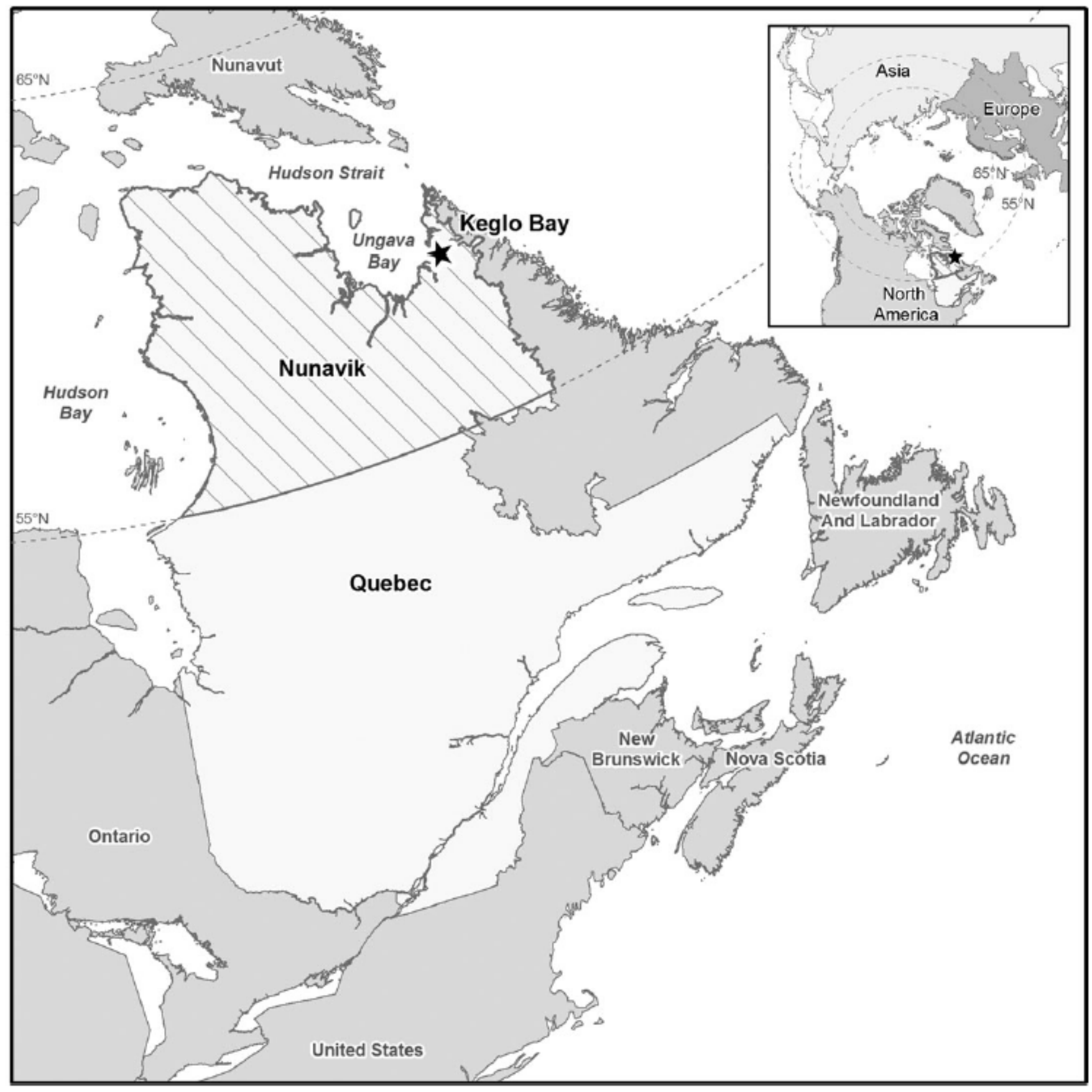




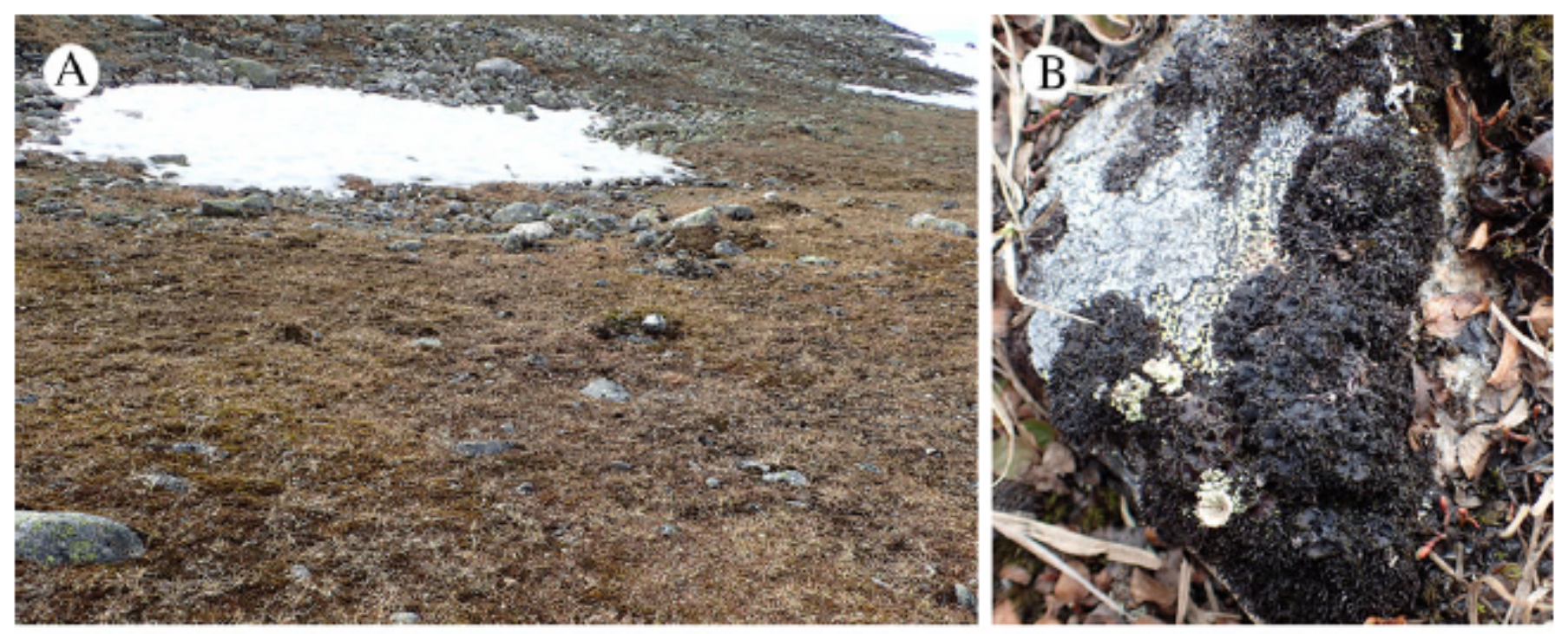

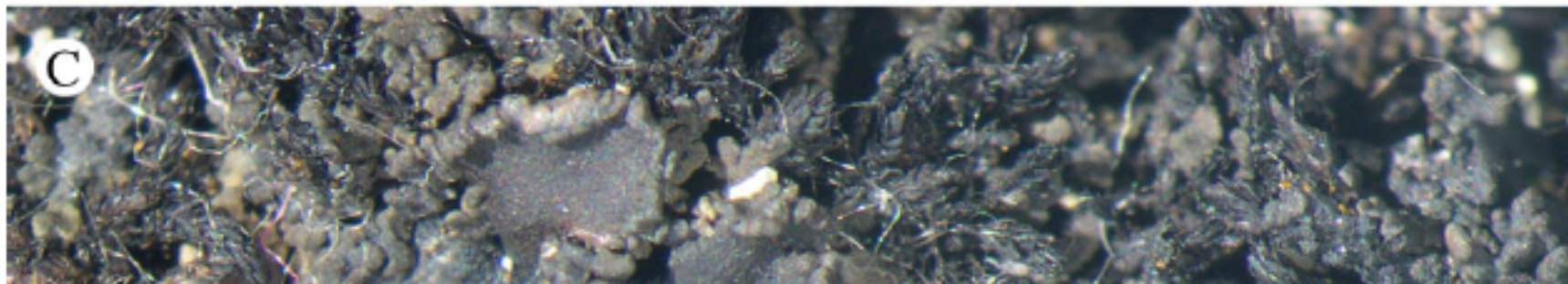

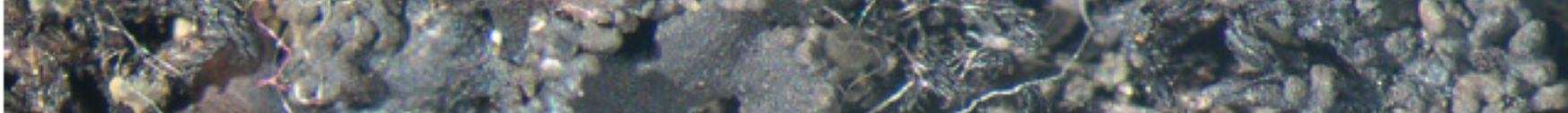
If

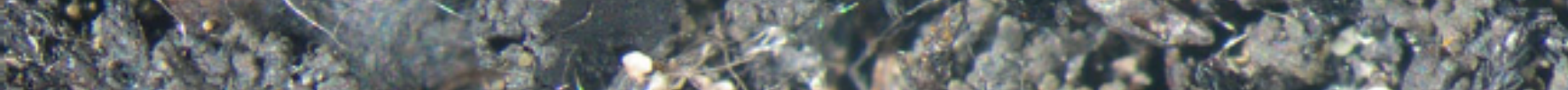

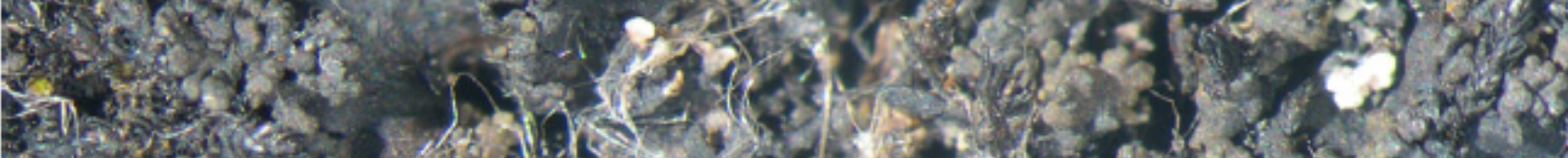

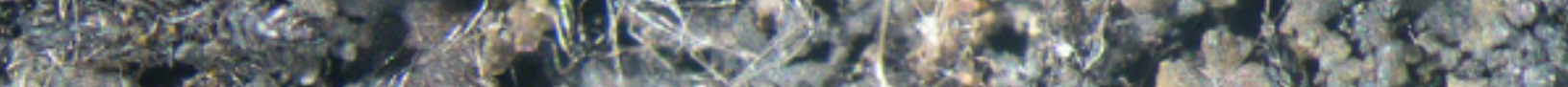

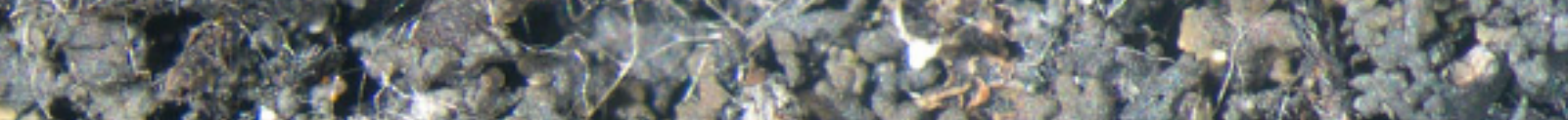

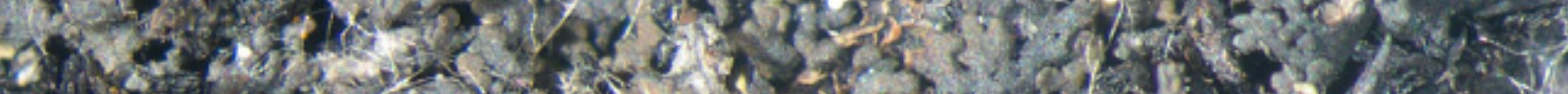

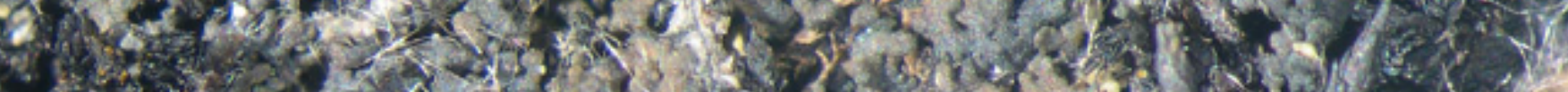

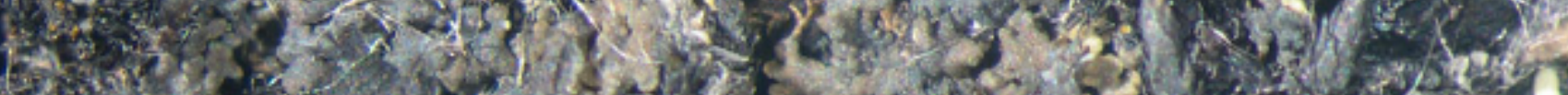

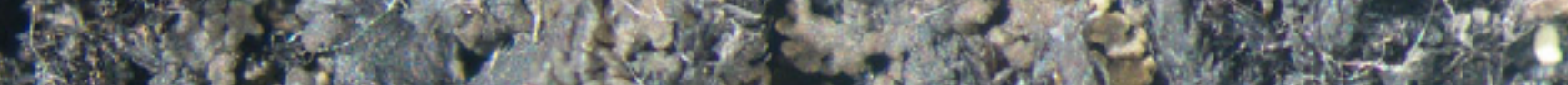

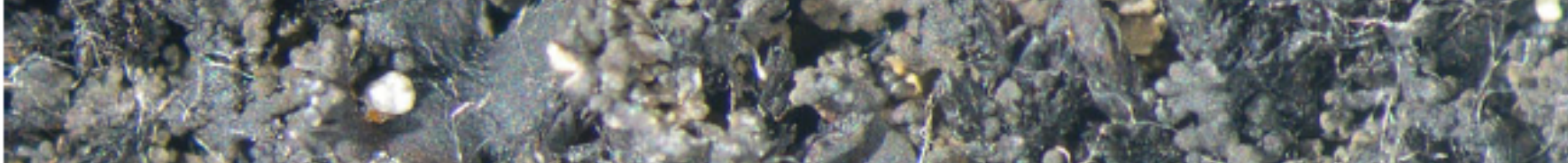

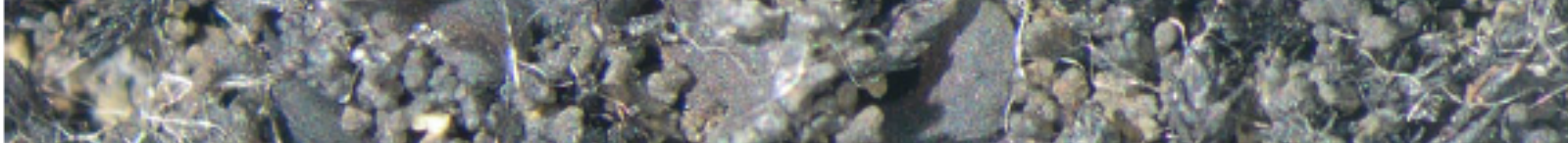

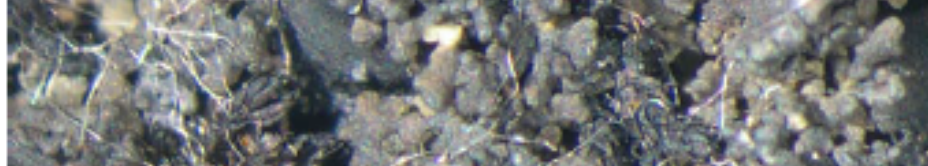

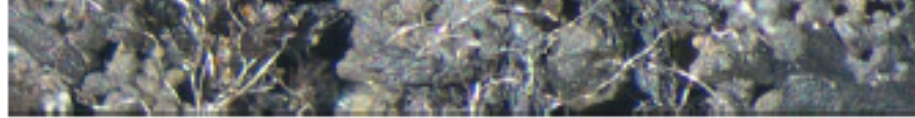

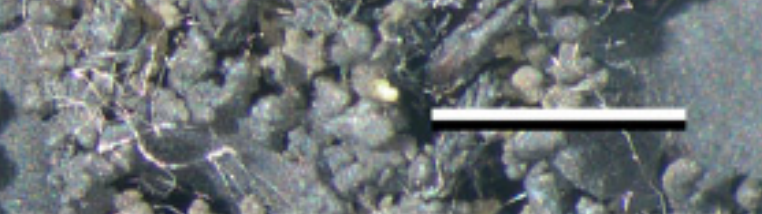



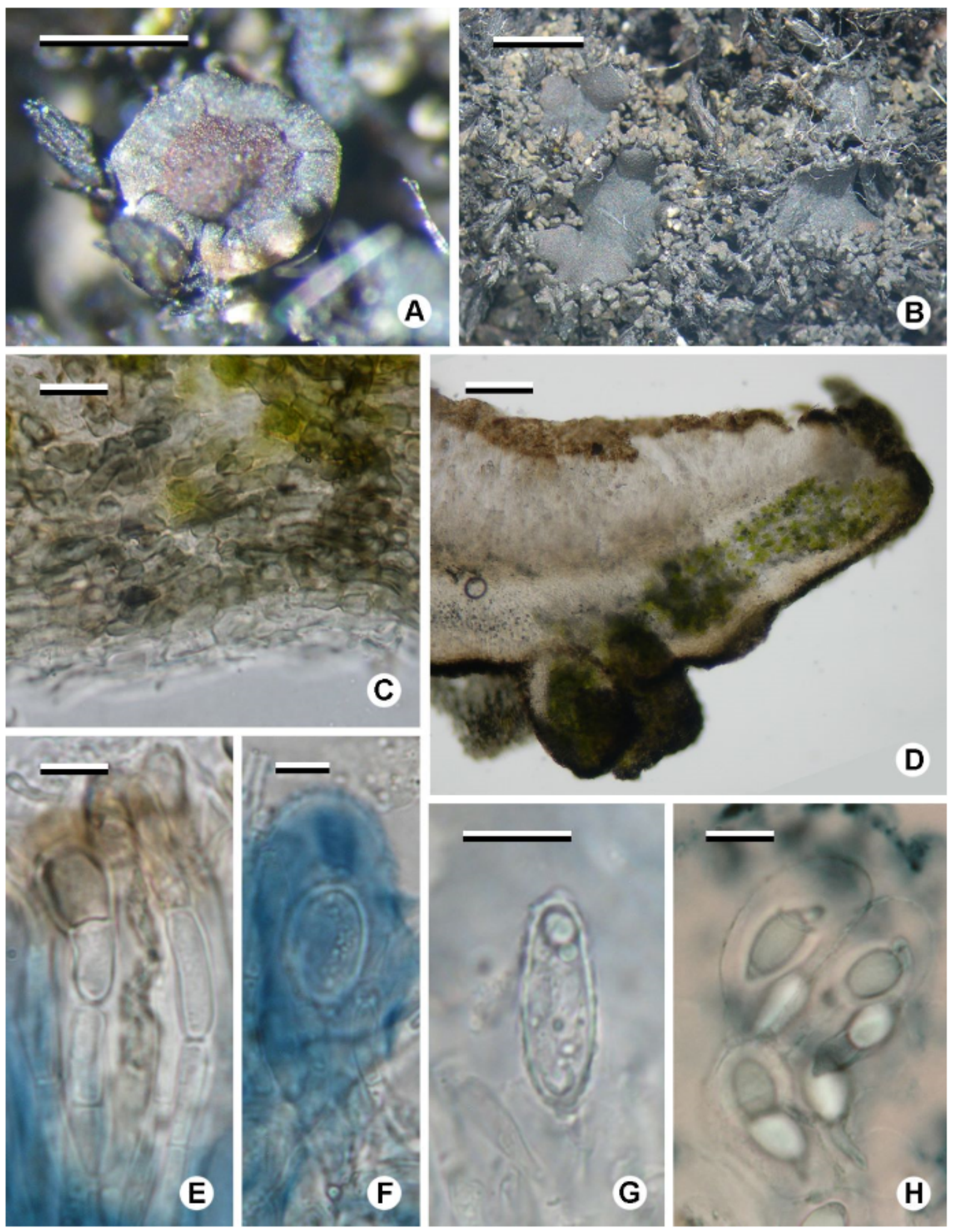

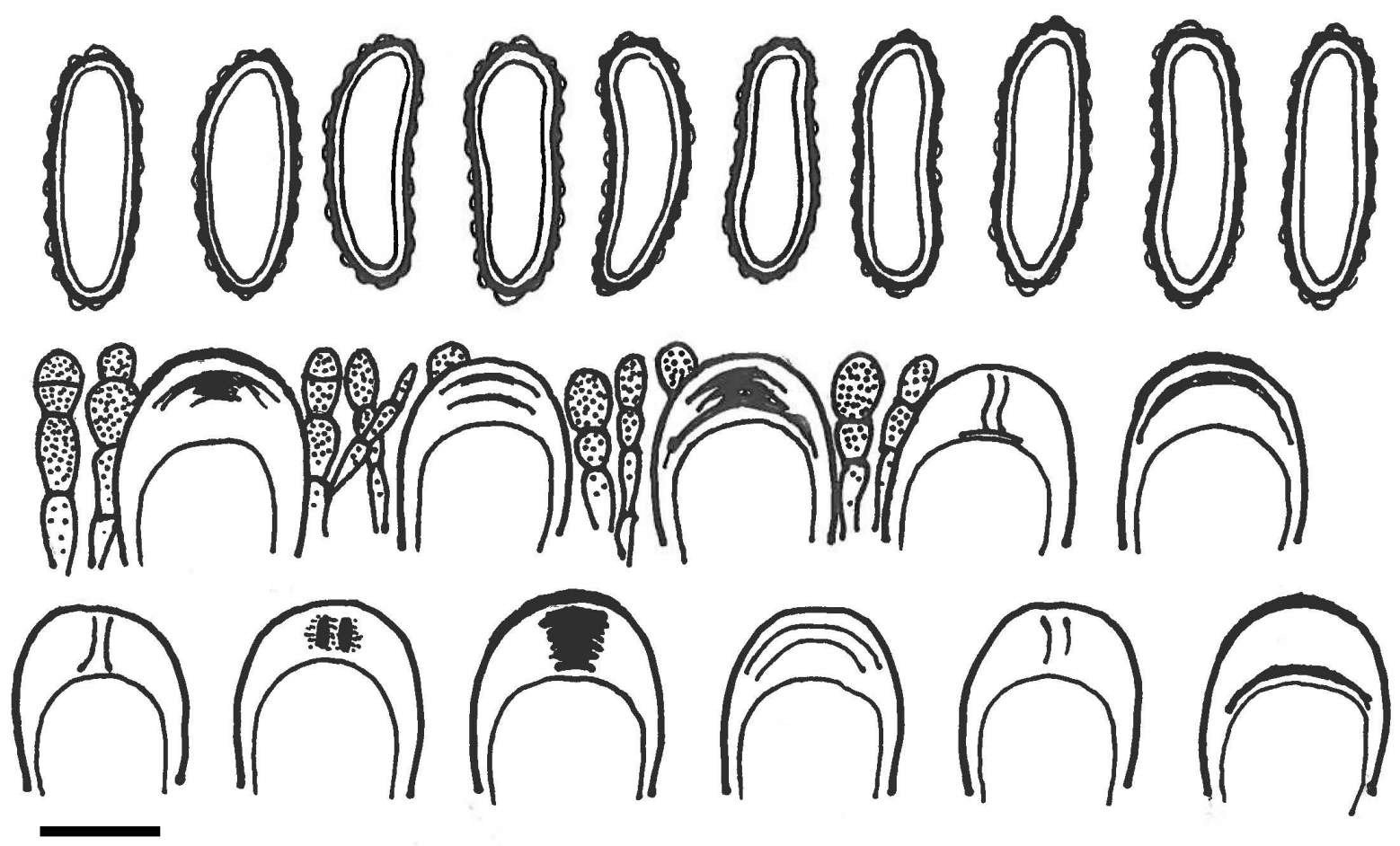